\title{
Changes in the Quality of Domestic Sewage Caused by the Reduction of Water Consumption in Households
}

\author{
Jarosław Chudzicki ${ }^{*}$, Katarzyna Umiejewska ${ }^{1}$ \\ 1 Warsaw Technical University, Faculty of Building Services, Hydro and Environmental Engineering, \\ 00-653 Warszawa, ul. Nowowiejska 20, Poland \\ * Corresponding author's e-mail: jaroslaw.chudzicki@pw.edu.pl
}

\begin{abstract}
Since the 1990s, there have been trends in Central and Eastern European countries to reduce water consumption. This phenomenon is closely related to the political, social and economic changes in these countries and the introduction of economic instruments in water management. The article presents the changes in water consumption in households in the years 1950-2019 depending on the degree of equipping buildings with sanitary facilities, and the structure of water consumption for particular purposes. For the same period, the quality of sewage generated in households is presented on the basis of bibliography. The content of total suspended solids was the main analysed parameter. The last part of the article presents the quality of wastewater discharged to fourteen Polish wastewater treatment plants. The majority of the analysed plants show an increase in the concentration of total suspended solids in the domestic sewage discharged to them. This phenomenon may be influenced by the decreasing water consumption in households.
\end{abstract}

Keywords: water consumption, saving water, municipal wastewater, total suspended solid

\section{INTRODUCTION}

Since the 1990s, the trends in the reduction of water consumption have been observed in the Central and Eastern European countries. This phenomenon is closely related to the economic changes in these countries and the introduction of economic instruments (e.g. water payment according to actual consumption).

Without questioning the need to save water and reduce its waste, this phenomenon has an increasingly significant impact on the operating conditions of both external sewage networks and wastewater treatment plants. An example of this may be the following trends:

- increase of pollutant concentration in wastewater (the same pollutant load is discharged in a smaller volume of wastewater),

- tendency for solids to precipitate from wastewater (no self-cleaning speed being maintained with unchanged slopes of the channels),
- technological problems in wastewater treatment plants,

- increase in the operating costs of the sewage system (higher frequency of pipe cleaning, flushing, etc.)

The article presents the changes in the parameters of domestic sewage discharged to municipal wastewater treatment plants over the last 70 years. These changes are closely linked to a reduction in the household water consumption due to various forms of water saving. In the future, the research can be used as a basis for verifying the existing principles of designing internal installations and external sewage networks.

\section{Changes in the volume and structure of water consumption in the years 1950-2019}

In the $1950 \mathrm{~s}$, there were no national standards or guidelines regarding the water demand indicators in Poland. It was then recommended 
to use the Soviet norms, e.g. Standard - 20 People's Commissariat of the Municipal Economy of the Russian Federal Soviet Republic of 1940 (Table 1) [Wóycicki, 1954].

According to the recommendations of the cited standard, the water consumption depends on the degree of equipping buildings with sanitary facilities and on the climatic conditions. Higher values of average daily water consumption refer to the southern zones of the USSR, and lower values refer to the northern zones. Using average values was recommended for the areas of Poland.

In this period, i.e. in the 1950 s, the structure of water consumption for domestic purposes in Polish households was as follows [Wojnarowicz, 1955]:

- toilet flushing (single use) $\quad-10-15 \mathrm{~L}$,

- bath (single use)

- shower (single use)

- watering the garden

$-200-300 \mathrm{~L}$,

$-40-80 \mathrm{~L}$,

$-11.5 \mathrm{~L} / \mathrm{m}^{2}$.

In 1966, the first national regulations concerning the determination of water demand were introduced in Poland. Apart from the given average values of water consumption, a method of forecasting the amount of water demand for domestic purposes for perspective and directional periods was included in the guidelines of the Ministry of Communal Management [Technical guidelines, 1966] (Table 2).

The structure of water consumption for particular domestic purposes in households in the 1960s is presented in Table 3 [Bortnowski, 1975]. It should be noted that the daily water consumption recorded in those times was significantly higher than the values assumed nowadays: 136-171 L/(person.d) depending on the method of hot water preparation.

The following factors contributed to a quite high level of water consumption in households [Chudzicki, Sosnowski, 2011]:

- the use of flat-rate accounting for the cold and hot water consumption (in relation to the number of inhabitants, to the household's surface), not related to the actual water consumption,

- lack of water saving habits and wasting water by system users, caused by a conviction that water should be a common good and free of charge for every consumer,

- use of poor quality installation materials (corroded pipes, failed toilet scrubbers, leaking faucets and taps, etc.),

- corrosivity of tap water, which shortens the time of installation operation, especially in steel pipes, (using high concentrations of aggressive disinfectants in water treatment plants).

These reasons had a direct impact on the disproportionately high water consumption in relation to the size of the load of pollutants discharged with domestic sewage.

As a result, the wastewater discharged from residential buildings was significantly diluted and contained lower concentrations of pollutants.

In the 1990s, a number of economic changes took place in Poland. As a result, the existing legal acts concerning the water demand indicators were amended in 2002 (Table 4). The amounts of

Table 1. Water consumption for domestic purposes [Wóycicki, 1954]

\begin{tabular}{|l|c|}
\hline \multicolumn{1}{|c|}{ Characteristics of sanitary facilities in buildings } & Average daily water consumption [L/(person·d)] \\
\hline $\begin{array}{l}\text { Buildings not equipped with water supply and sewage systems, } \\
\text { when using public water taps }\end{array}$ & $30 \div 50$ \\
\hline Buildings with water supply and sewage systems & $60 \div 80$ \\
\hline $\begin{array}{l}\text { Buildings with water supply and sewage systems as well as } \\
\text { bathrooms with local heating }\end{array}$ & $90 \div 120$ \\
\hline Buildings provided with central hot water as well & $150 \div 200$ \\
\hline
\end{tabular}

Table 2. Water consumption for domestic purposes accepted for design according to [Gabryszewski, 1978] [Technical guidelines, 1966]

\begin{tabular}{|l|c|}
\hline \multicolumn{1}{|c|}{ Household water supply equipment } & $\begin{array}{c}\text { Average water consumption } \\
\text { [L/(person·d)] }\end{array}$ \\
\hline $\begin{array}{l}\text { Drinking water supplied to households with a kitchen sink, a flushing toilet and bathing } \\
\text { appliances supplied with hot water from a multi-combustible gas (electric) flow furnace }\end{array}$ & 160 \\
\hline $\begin{array}{l}\text { Water supply to households equipped with a kitchen sink, a flushing toilet and bathing } \\
\text { appliances supplied with centrally prepared hot water from a boiler in the kitchen }\end{array}$ & 185 \\
\hline
\end{tabular}


Table 3. Structure of water consumption intended for domestic purposes in the 1960s [Bortnowski, 1975]

\begin{tabular}{|l|c|c|}
\hline \multirow{2}{*}{\multicolumn{1}{|c|}{ Water demand goals }} & \multicolumn{2}{c|}{ Water consumption [L/(person·d)] } \\
\cline { 2 - 3 } & $\begin{array}{c}\text { Full water supply and sewage } \\
\text { system, gas flow furnaces }\end{array}$ & $\begin{array}{c}\text { Full water supply and sewage } \\
\text { system, centrally prepared hot } \\
\text { water }\end{array}$ \\
\hline Drinking and meal preparation & 5 & 5 \\
\hline Washing dishes and floors & 10 & 10 \\
\hline Washing hands and face & 10 & 15 \\
\hline Taking a shower (once a day) & 25 & 40 \\
\hline Bathing (once a week) & 40 & 50 \\
\hline Toilet flushing & $18 \div 36$ & $18 \div 36$ \\
\hline Laundry & 15 & 20 \\
\hline Other purposes & 4 & $\mathbf{1 7 1}$ \\
\hline Total & $\mathbf{1 3 6}$ & $\mathbf{1 7 1}$ \\
\hline
\end{tabular}

Table 4. Average water consumption in households [Journal of Laws, 2002]

\begin{tabular}{|l|c|c|}
\hline \multicolumn{1}{|c|}{ Household water supply equipment } & \multicolumn{2}{c|}{ Average water consumption standards } \\
\cline { 2 - 3 } & {$[\mathrm{L} /($ person·d $]$} & {$\left[\mathrm{m}^{3} /(\right.$ person $\left.\cdot \mathrm{month})\right]$} \\
\hline Water supply system - public water taps & $50 \div 60^{*}$ & 0.9 \\
\hline Water supply - draw-off valve on the staircase & $70 \div 90^{*}$ & $1.5 \div 1.8^{*}$ \\
\hline Water supply, kitchen sink, toilet (no bathroom and no hot water) & $80 \div 100^{*}$ & $2.10 \div 2.70^{*}$ \\
\hline $\begin{array}{l}\text { Water supply, flushing toilet, bathroom, local hot water source (coal } \\
\text { stove, gas flow furnaces, electric boiler) }\end{array}$ & $140 \div 3.0^{*}$ \\
\hline $\begin{array}{l}\text { Water supply, flushing toilet, bathroom, hot water supply to the } \\
\text { household (central hot water preparation) }\end{array}$ & $4.2 \div 5.4^{*}$ \\
\hline $\begin{array}{l}\text { * Lower values refer to buildings in the areas without sewage system and higher values refer to buildings connected to sewerage } \\
\text { systems. }\end{array}$ \\
\hline
\end{tabular}

water demand specified in the Regulation [Journal of Laws, 2002] are still used for planning and designing purposes.

After the year 2000, the structure of water consumption in households did not change significantly in comparison to the previous years (Table 5).

Similar values of water demand and structure of water consumption for domestic purposes are given in Germany (Table 6) [VDI 6024, 2003].

After analysing the chronological changes in the water demand indicators in the legislation and guidelines and taking into account the changes in the actual domestic water consumption, it can be concluded that there has been significant progress in the development of sanitation technology, which has a measurable impact on water saving.

The most important technical solutions for saving water in households include [Chudzicki, Sosnowski, 2011]:

- equipping households with water meters and accounting for the costs of water supply on the basis of their indications,

- the use of water saving appliances in conjunction with the development of appropriate habits for water use (thermostatic, electronic opening and closing tapware, automatic shutoff valves, water-saving toilet bowls and urinals, more widespread use of shower cubicles instead of bathtubs),

- improvement of hot water circuits and installation of devices ensuring maintenance of the desired water temperature (proper insulation of pipes, regulation and balancing of circulation circuits),

- central and local reduction of the water pressure,

- using grey water instead of tap water for certain purposes,

- use of rainwater in households.

\section{Changes in the quality of raw sewage inflow to the wastewater treatment plant in the years 1933-2019}

The consequence of significant changes in the amount of water consumption in households is a change in the quality composition of the household sewage.

The main indicators of the wastewater quality in the 1930s included general suspension and the content of organic compounds marked as $\mathrm{BOD}_{5}$. 
Table 5. Structure of water consumption for domestic purposes [Chudzicki, Sosnowski, 2011]

\begin{tabular}{|l|c|c|c|}
\hline \multirow{2}{*}{ Water demand goals } & \multicolumn{2}{c|}{ Water consumption [L/(person·d)] } & \multirow{2}{*}{$\%$} \\
\cline { 2 - 4 } & min $\div \max$ & average & 3 \\
\hline Drinking and meal preparation & $3 \div 5$ & 4 & 10 \\
\hline Washing dishes & $10 \div 15$ & 12 & 10 \\
\hline Washing the body & $10 \div 15$ & 33 & 26 \\
\hline Shower or bath & $25 \div 40$ & 38 & 30 \\
\hline Toilet flushing & $30 \div 45$ & 18 & 15 \\
\hline Laundry & $16 \div 20$ & 8 & 6 \\
\hline Cleaning and other needs & $6 \div 10$ & $\mathbf{1 2 5}$ & $\mathbf{1 0 0}$ \\
\hline Total & $\mathbf{1 0 0} \div \mathbf{1 5 0}$ & & \\
\hline
\end{tabular}

Table 6. Unit values of water demand in Germany [VDI 6024, 2003]

\begin{tabular}{|l|c|c|}
\hline \multicolumn{1}{|c|}{ Water demand goals } & $\begin{array}{c}\text { Percentage share } \\
{[\%]}\end{array}$ & $\begin{array}{c}\text { Water consumption } \\
[\mathrm{L} /(\mathrm{pers}) \mathrm{d})]\end{array}$ \\
\hline Toilet flushing & 27 & 34 \\
\hline Body hygiene, bath, shower & 36 & 46 \\
\hline Drinking and meal preparation & 4 & 5 \\
\hline Cleaning the apartment, washing the car, watering the garden & 6 & 8 \\
\hline Small business activities & 9 & 11 \\
\hline Laundry Total & 12 & 15 \\
\hline \multicolumn{1}{|c|}{100} & 127 \\
\hline
\end{tabular}

The data used for the design of wastewater treatment plants were based on the quality indicators provided by Imhoff (Table 7).

Table 7 shows that the typical suspended solids concentration in municipal wastewater in the 1930s was $420 \mathrm{mg} / \mathrm{L}$ and $\mathrm{BOD}_{5}-300 \mathrm{mgO}_{2} / \mathrm{L}$. The guide also included a statement that: "Depending on the local conditions, the amount of water used and the amount of pollution, the composition of the sewage varies over the course of the day. The maximum outflow of wastewater takes place between 10 a.m. and 4 p.m. During these hours the pollutant content of wastewater is the highest. Imhoff [Imhoff, 1933] also states that the water consumption in the United States is three or four times higher, so the wastewater is proportionally diluted [Janczewski, 1973].

In the handbook "Water supply and sewage systems" published in 1948, Wóycicki states that: "The concentration of domestic sewage in cities, where the water intake does not reach $100 \mathrm{~L} /($ person.d), is much higher than in the cities of Central Europe, where the standard is 150-250 L/(person.d), or in America with the partition reaching $1000 \mathrm{~L} /($ person.d). However, the amount of dirt per inhabitant varies slightly. The amount of water only acts as a dilution agent." [Wóycicki, 1948].

The composition of pollution of average municipal wastewater was then assumed according to Table 8 . Thus, it can be noted that in the period after the Second World War, the concentration of suspended solids and the value of BOD 5 increased in comparison to the 1930s (Table 7). Table 9 shows that typical suspended solids concentration in municipal wastewater was $600 \mathrm{mg} / \mathrm{L}$ and $\mathrm{BOD}_{5} 360 \mathrm{mgO}_{2} / \mathrm{L}$ (increase in total suspended solids concentration by $43 \%$ and the $\mathrm{BOD}_{5}$ values by $20 \%$ compared to the Imhoff's recommendations of 1933).

Table 7. Average composition of wastewater from Germany cities using $150 \mathrm{~L} /($ person $\cdot d)$ water, according to [Imhoff, 1933]

\begin{tabular}{|l|c|c|c|c|}
\hline \multicolumn{1}{|c|}{ Parameter } & Mineral & Organic & Total & BOD $_{5}$ \\
\hline Total solids [mg/L] & 120 & 300 & 420 & 160 \\
\hline Settleable solid [mg/L] & 90 & 200 & 290 & 100 \\
\hline Non-settleable solid [mg/L] & 30 & 100 & 130 & 60 \\
\hline Dissolved solid [mg/L] & 300 & 150 & 450 & 140 \\
\hline Total [mg/L] & $\mathbf{4 2 0}$ & $\mathbf{4 5 0}$ & $\mathbf{8 7 0}$ & $\mathbf{3 0 0}$ \\
\hline
\end{tabular}


Table 8. Urban wastewater composition according to [Wóycicki, 1948]

\begin{tabular}{|l|c|c|c|c|}
\hline \multicolumn{1}{|c|}{ Parameters } & Mineral & Organic & Total & BOD $_{5}$ \\
\hline Total solids [mg/L] & 200 & 400 & 600 & 210 \\
\hline Settleable solids [mg/L] & 130 & 270 & 400 & 130 \\
\hline Non-settleable solids [mg/L] & 70 & 130 & 200 & 80 \\
\hline Dissolved substances [mg/L] & 330 & 330 & 660 & 150 \\
\hline Total [mg/L] & $\mathbf{5 3 0}$ & $\mathbf{7 3 0}$ & $\mathbf{1 2 6 0}$ & $\mathbf{3 6 0}$ \\
\hline
\end{tabular}

Wóycicki states that the amount of pollution per capita depends on the life habits and the degree of wealth [Wóycicki, 1948]. For the Central European conditions, the unit values of pollutant loads from Table 9 were assumed.

In 1948, the notion of a unit suspended solid load of $90 \mathrm{~g} /($ person $\cdot \mathrm{d})$ appeared as well as the unit $\mathrm{BOD}_{5}$ load of $54 \mathrm{~g} /($ person $\cdot \mathrm{d})$. At that time, wastewater treatment plants carried out only the treatment processes based on straining, sedimentation, flotation and removal of organic compounds under the conditions similar to natural (aeration tanks, trickling filters).

In the Imhoff's guide of 1957 [Imhoff, 1957] and 1970 [Imhoff, 1970] the same pollutant concentrations and unit loads were quoted, which were given by Wóycicki in 1948. Significant changes in the average composition of sewage in European cities were presented in the next edition of the Imhoff's guide from 1982 [Imhoff, 1987] (Table 10 and 11).
According to [Imhoff, 1982] "Water consumption other than $200 \mathrm{~L} /($ person'd) causes a change in sewage concentration, because with higher water consumption the amount of pollution per capita increases slightly".

Since 1982, a unit load of total suspended solids $55 \mathrm{~g} /($ person $\cdot d)$ and a unit load of $\mathrm{BOD}_{5}-$ $60 \mathrm{~g} /($ person $\cdot \mathrm{d})$ started to be taken into account for design (Table 11).

In Imhoff's Guide of 1996 [Imhoff, Imhoff, 1996], the unit load of a total suspension $65 \mathrm{~g} /($ person $\cdot \mathrm{d})$ - was changed.

In the guidelines for the design of wastewater treatment plants issued in Poland in 2001, the following unit loads of pollutants in the amount are given [ATV-DVWK, 2001]:

- $\mathrm{BOD}_{5}-60 \mathrm{gO}_{2} /($ person$\cdot \mathrm{d})$,

- $\mathrm{COD}-120 \mathrm{gO}_{2} /$ (person.d),

- Total suspended solid (TSS) - $70 \mathrm{~g} /($ person·d),

- Total nitrogen $-11 \mathrm{~g} /($ person $\cdot \mathrm{d})$,

- Total phosphorus - $1.8 \mathrm{~g} /($ person·d).

Table 9. Unit pollution loads for urban wastewater according to [Wóycicki, 1948]

\begin{tabular}{|l|c|c|c|c|}
\hline \multicolumn{1}{|c|}{ Parameters } & Mineral & Organic & Total & BOD $_{5}$ \\
\hline Total solids [g/(person·d)] & 30 & 60 & 90 & 31 \\
\hline Settleable solids [g/(person·d)] & 20 & 40 & 60 & 19 \\
\hline Non-settleable solids [g/(person·d)] & 10 & 20 & 30 & 12 \\
\hline Dissolved substances[g/(person·d)] & 50 & 50 & 100 & 23 \\
\hline Total [g/(person·d)] & $\mathbf{8 0}$ & $\mathbf{1 1 0}$ & $\mathbf{1 9 0}$ & $\mathbf{5 4}$ \\
\hline
\end{tabular}

Table 10. Municipal wastewater composition according to [Imhoff, 1982]

\begin{tabular}{|l|c|c|c|c|}
\hline \multicolumn{1}{|c|}{ Parameters } & Mineral & Organic & Total & BOD $_{5}$ \\
\hline Settleable solids $[\mathrm{mg} / \mathrm{L}]$ & 50 & 150 & 200 & 100 \\
\hline Non-settleable solids [mg/L] & 25 & 50 & 75 & 50 \\
\hline Dissolved substances [mg/L] & 375 & 250 & 625 & 150 \\
\hline Total [mg/L] & $\mathbf{4 5 0}$ & $\mathbf{4 5 0}$ & $\mathbf{9 0 0}$ & $\mathbf{3 0 0}$ \\
\hline
\end{tabular}

Table 11. Unit pollution loads for municipal wastewater according to [Imhoff, 1982]

\begin{tabular}{|l|c|c|c|c|}
\hline \multicolumn{1}{|c|}{ Parameters } & Mineral & Organic & Total & BOD $_{5}$ \\
\hline Settleable solids [g/(person·d)] & $\mathbf{1 0}$ & $\mathbf{3 0}$ & 40 & 20 \\
\hline Non-settleable solids [g/(person·d)] & $\mathbf{5}$ & $\mathbf{1 0}$ & 15 & 10 \\
\hline Dissolved substances [g/(person·d)] & $\mathbf{7 5}$ & 50 & 125 & 30 \\
\hline Total [g/(person·d)] & $\mathbf{9 0}$ & $\mathbf{9 0}$ & $\mathbf{1 8 0}$ & $\mathbf{6 0}$ \\
\hline
\end{tabular}


Table 12. Concentrations of pollutant in wastewater

\begin{tabular}{|l|c|c|c|}
\hline \multirow{2}{*}{ Parameter } & \multicolumn{2}{|c|}{ Pollutant concentration in [mg/L] depending on water consumption: } \\
\cline { 2 - 4 } & $100[\mathrm{~L} /($ person $\cdot d)]$ & $120[\mathrm{~L} /($ person $\cdot d)]$ & $150[\mathrm{~L} /($ person $\cdot d)]$ \\
\hline TSS & 700 & 580 & 460 \\
\hline $\mathrm{BOD}_{5}$ & 600 & 500 & 400 \\
\hline $\mathrm{COD}$ & 1200 & 1000 & 800 \\
\hline Total nitrogen & 110 & 92 & 73 \\
\hline Total phosphorus & 18 & 15 & 12 \\
\hline
\end{tabular}

The new indicators unit load of suspended solid and $\mathrm{BOD}_{5}$ were introduced in these guidelines. The concentrations of pollutants depend on the specific water consumption; therefore, Table 12 gives the examples of the pollutant concentrations resulting from different water consumption in households. Table 12 indicates that specific water consumption translates into the content of total suspended solids in domestic wastewater. A reduction of specific water consumption increases the concentration of pollutants.

As it can be concluded from the presented analyses of literature as well as the quoted guidelines and regulations containing basic indicators of sewage quality, these indicators have undergone significant changes over the past 90 years. These changes (increases or decreases) are related to the shifts in the volume of water consumption, the development of building sanitation and the changes in residents' habits.

According to [Sytek-Szmeichel et al., 2015] on the basis of data collected from 77 Polish wastewater treatment plants, the unit load of total suspended solids in raw sewage can be assumed at the level of $74 \mathrm{~g} /($ person $\cdot \mathrm{d})$, which at the unit amount of sewage $150 \mathrm{~L} /($ person $\cdot d)$ corresponds to the suspended solids concentration of $495 \mathrm{mg} / \mathrm{L}$. These studies confirm the increase in the unit load of total suspended solids in raw sewage.

\section{MATERIALS AND METHODS}

The analysis covered parameters in raw sewage in the following scope:

- TSS - PN-EN 872:2007,

- $\mathrm{BOD}_{5}$ - PN-EN 1899-1:2002,

A data collection from the years 2003-2018 was available from 7 Polish WWTPs operating from 40150 to 147000 PE. An annual average was calculated for each plant based on 24 values of daily averages, made available by the plant. Consequently, a set of data for particular years was created (total of 112 records).

In order to determine the changes in the parameters in raw sewage, the value of the indicator in the first year of analysis was assumed for each plant as a basic value against which the percentage changes (increases or decreases) of values in subsequent years were calculated.

After reviewing the literature, it was found that the key parameters for assessing the impact of the quantity of water used on the quality of raw sewage were the TSS content and $\mathrm{BOD}_{5}$ values.

\section{RESULTS AND DISCUSSION}

\section{Total Suspended Solids}

In order to assess the changes in the TSS content of raw sewage, a simplified statistical analysis of the collected data set was conducted (Table 13).

Table 13 shows that for the five years 2006-2008, 2012 and 2015, the minimum changes of the TSS content were not lower than the base value adopted for 2003. Furthermore, it should be noted that in each year, the average value is higher than zero, which indicates a relative increase of the suspended solids content in wastewater. In the years 2012-2018 the average increase in the TSS content from 7 Polish treatment plants is close to $30 \%$. The highest average was obtained for $2015-55.0 \%$.

When evaluating the median for particular years, it can be concluded that the values above zero occurred only in the years 2012-2014, which indicates that in these years more than half of the analysed wastewater treatment plants achieved a relative increase in the suspended solids content. 
Table 13. Comparison of the characteristic values of TSS in raw wastewater.

\begin{tabular}{|c|c|c|c|c|c|c|}
\hline \multirow{2}{*}{ Year } & \multicolumn{3}{|c|}{ Changes [\%] } & \multirow{2}{*}{$\begin{array}{l}\text { Standard } \\
\text { deviation }\end{array}$} & \multirow{2}{*}{$\begin{array}{l}\text { Coefficient of } \\
\text { variation }\end{array}$} & \multirow{2}{*}{ Median } \\
\hline & Min & Average & Max & & & \\
\hline 2004 & -8.7 & 14.5 & 51.8 & 32.6 & 2.3 & 0.0 \\
\hline 2005 & -9.0 & 2.0 & 13.0 & 15.6 & 7.8 & 0.0 \\
\hline 2006 & 0.0 & 42.3 & 58.9 & 23.5 & 0.6 & 0.0 \\
\hline 2007 & 0.0 & 27.1 & 38.8 & 15.7 & 0.6 & 0.0 \\
\hline 2008 & 0.0 & 14.6 & 37.5 & 20.1 & 1.5 & 0.0 \\
\hline 2009 & -10.3 & 6.1 & 24.2 & 16.4 & 2.7 & 0.0 \\
\hline 2010 & -0.7 & 22.9 & 64.1 & 28.5 & 1.2 & 0.0 \\
\hline 2011 & -4.9 & 17.6 & 74.0 & 32.5 & 1.8 & 0.0 \\
\hline 2012 & 0.0 & 35.3 & 72.1 & 24.9 & 0.7 & 25.1 \\
\hline 2013 & -19.2 & 29.6 & 86.2 & 35.9 & 1.2 & 18.6 \\
\hline 2014 & -32.4 & 31.1 & 95.9 & 41.2 & 1.3 & 31.3 \\
\hline 2015 & 0.0 & 55.0 & 131.8 & 53.1 & 1.0 & 9.5 \\
\hline 2016 & -20.1 & 25.0 & 67.0 & 41.3 & 1.7 & 0.0 \\
\hline 2017 & -27.7 & 38.0 & 76.1 & 46.4 & 1.2 & 0.0 \\
\hline 2018 & -50.8 & 34.0 & 89.3 & 59.7 & 1.8 & 0.0 \\
\hline
\end{tabular}

The values of standard deviation indicate high heterogeneity of the data set. In all analysed years, the coefficient of variation exceeded 0.6 , which confirms the previous hypothesis. The TSS content in raw sewage is influenced by a number of different factors which are not fully identified (e.g. habits of residents using the sewage system).

Figures 1 and 2 shows a change in the total suspended solids content in raw sewage for the 7 analyzed wastewater treatment plants (WWTP1, WWTP2, etc) in years 2003-2018.

\section{$\mathrm{BOD}_{5}$ value}

Another parameter covered by the analysis was $\mathrm{BOD}_{5}$ (Table 14). The minimum $\mathrm{BOD}_{5}$ values in the analysed years are almost always below zero (except for 2008 and 2015), which indicates that there is no noticeable increase in $\mathrm{BOD}_{5}$ in wastewater in subsequent years. In 2004 and 2011, no increase in the $\mathrm{BOD}_{5}$ values was found at any of the treatment plants compared to the base value in 2003. No median value higher than 0 was found at any wastewater

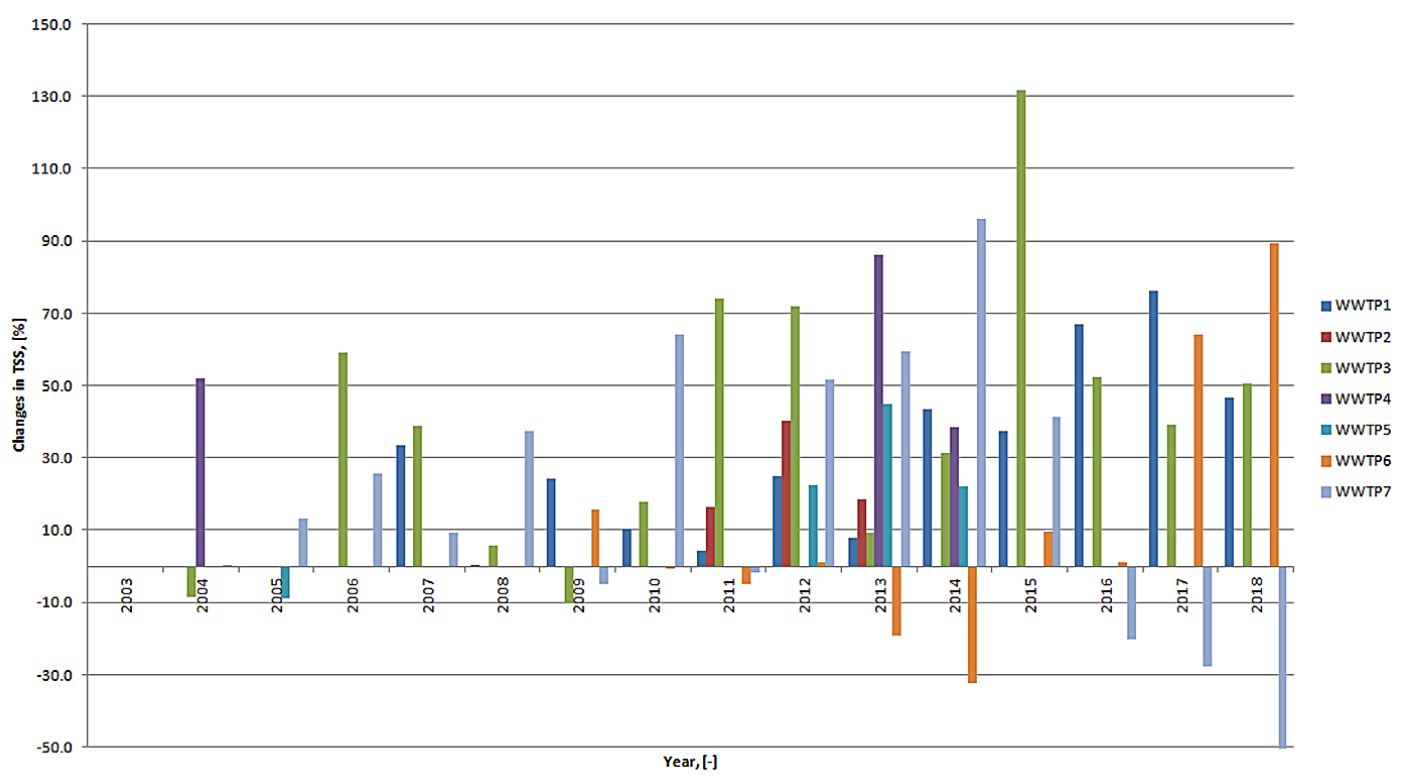

Figure 1. Changes in the TSS concentration in the analysed treatment plants 


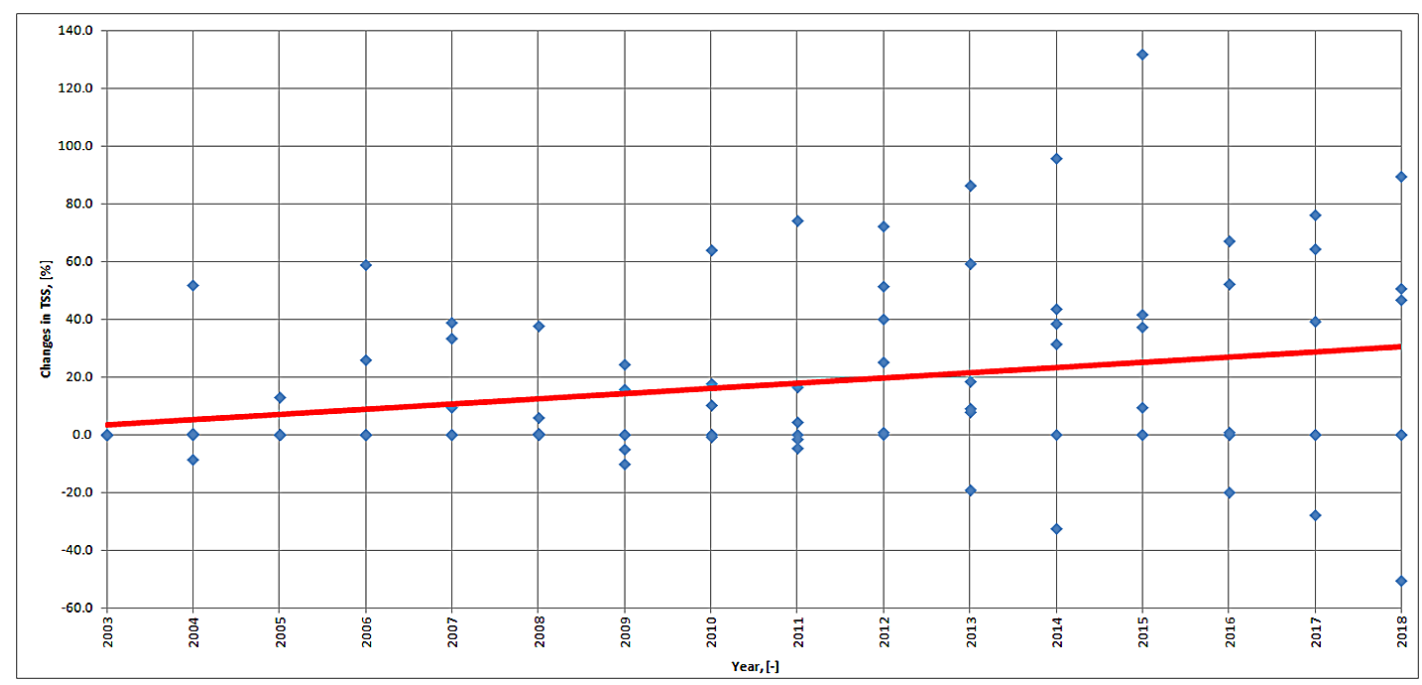

Figure 2. Percentage changes in the value of TSS with the trend line

Table 14. Comparison of the characteristic values of $\mathrm{BOD}_{5}$ in raw wastewater

\begin{tabular}{|c|c|c|c|c|c|c|}
\hline \multirow{2}{*}{ Year } & \multicolumn{3}{|c|}{ Changes [\%] } & \multirow{2}{*}{$\begin{array}{c}\text { Standard } \\
\text { deviation }\end{array}$} & $\begin{array}{c}\text { Coefficient } \\
\text { of variation }\end{array}$ & Median \\
\cline { 2 - 4 } & Min & Average & Max & 10.3 & 1.3 & 0.0 \\
\hline 2004 & -15.9 & -8.0 & 0.0 & 9.8 & 10.8 & 0.0 \\
\hline 2005 & -9.0 & -0.9 & 12.8 & 16.3 & 3.8 & 0.0 \\
\hline 2006 & -7.2 & -4.3 & 15.8 & 17.1 & 5.2 & 0.0 \\
\hline 2008 & -7.2 & 3.3 & 23.1 & 14.4 & 0.7 & 0.0 \\
\hline 2009 & 0.0 & 19.6 & 35.7 & 21.5 & 2.5 & 0.0 \\
\hline 2010 & -21.4 & 8.7 & 23.7 & 15.5 & 5.2 & 0.0 \\
\hline 2011 & -19.7 & -3.0 & 17.5 & 7.2 & 2.3 & -6.8 \\
\hline 2012 & -7.5 & 6.0 & 17.7 & 13.5 & 271.1 & 0.0 \\
\hline 2013 & -34.3 & 0.1 & 45.0 & 27.1 & 2.3 & 0.3 \\
\hline 2014 & -32.4 & 41.5 & 206.9 & 97.2 & 0.3 & 0.0 \\
\hline 2015 & 0.0 & 22.4 & 27.4 & 7.0 & 3.8 & 0.0 \\
\hline 2016 & -22.0 & 12.5 & 67.3 & 48.0 & 2.8 & 0.0 \\
\hline 2017 & -33.3 & 15.2 & 44.5 & 42.3 & 5.7 & 0.0 \\
\hline 2018 & -31.7 & 8.7 & 64.3 & 49.8 & & 0.0 \\
\hline
\end{tabular}

treatment plant, which indicates that there was no increase in the $\mathrm{BOD}_{5}$ values for more than half of the data collected.

The dispersion of individual data values is characterised by the value of the standard deviation parameter and the coefficient of variation. Only in the years 2011 and 2015, the values of the coefficient of variation were obtained, which proves a high variability of data. In the remaining years the variability of data is very high.

At the same time, it should be noted that in 2014 there was a maximum value of $\mathrm{BOD}_{5}$ significantly deviating from the other records. Such a value can be qualified as a gross error in the analysed data set and should be omitted.

\section{CONCLUSIONS}

It was found that with an increase in water consumption in the years 1950-1990, the provisions of the guidelines and indicators for programming water demand for project purposes were also changed. Between the years 1990 and 


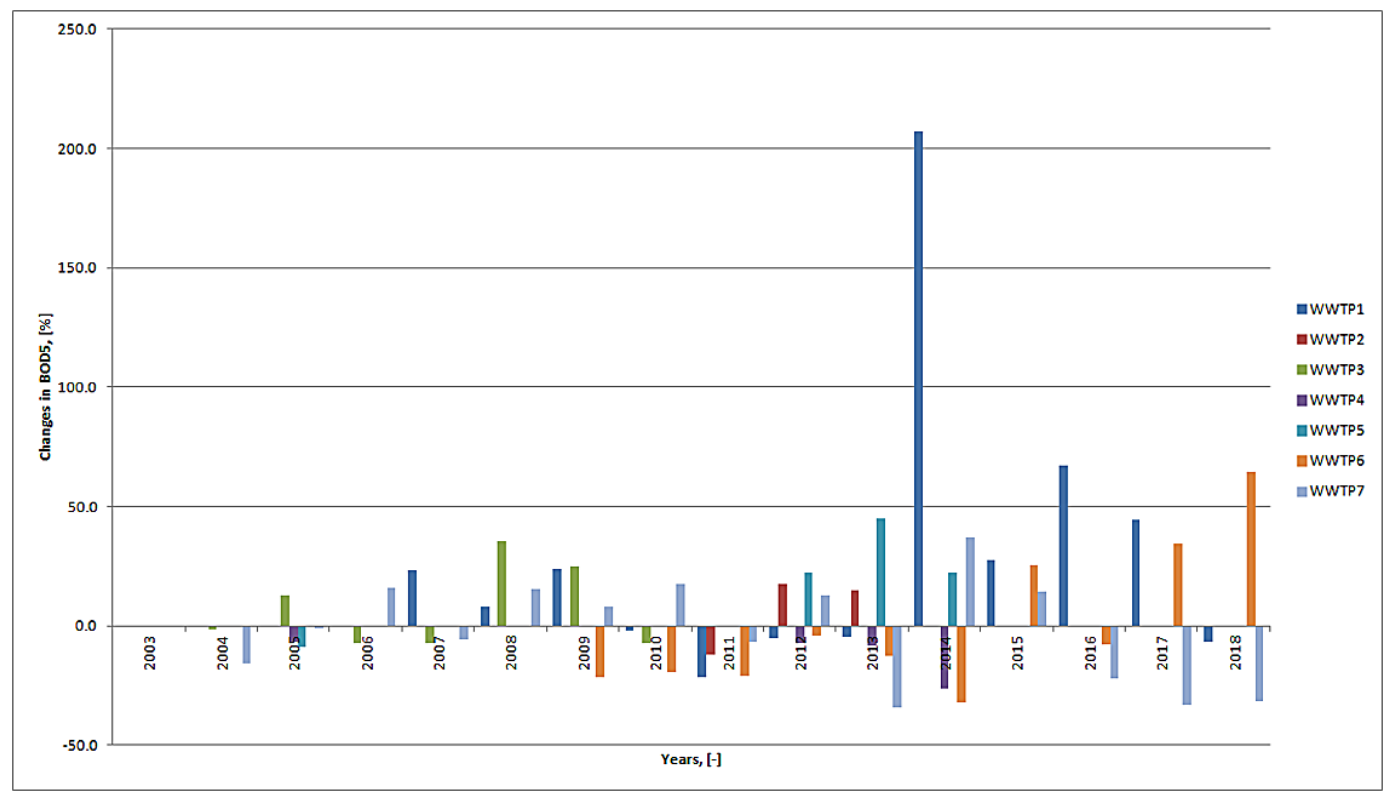

Figure 3. Changes in $\mathrm{BOD}_{5}$ in the analysed treatment plants

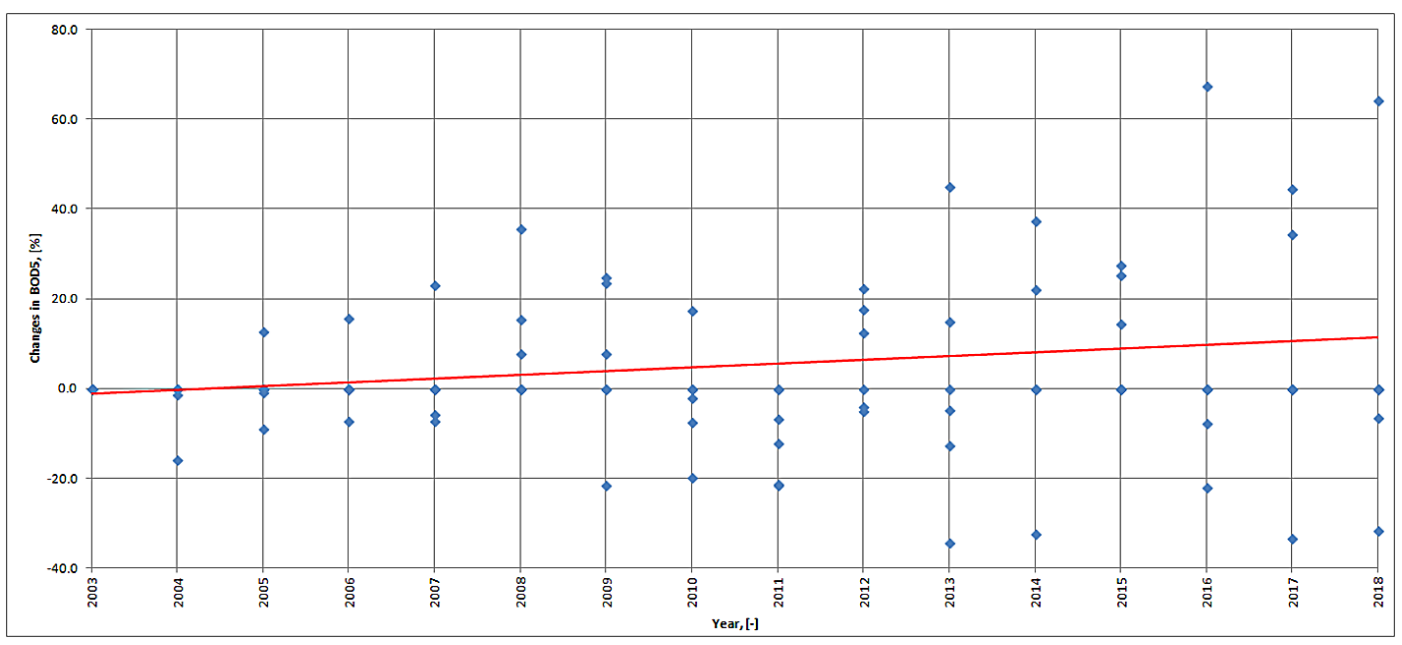

Figure 4. Percentage changes in $\mathrm{BOD}_{5}$ including the trend line

2000 , there was a clear change in the trend of water consumption, with the demand for water in residential buildings starting to decrease.

At the same time, the changes in the legal regulations defining the indicators of pollution of domestic sewage flowing into wastewater treatment plants were analysed. Due to the impact of the sewage composition on the problems related to the gravitational discharge of domestic sewage in internal sewage systems and external networks, the analysis included such indicators as general suspension, and $\mathrm{BOD}_{5}$.

In order to verify the observed tendencies of changes in legal regulations, the actual values of selected indicators of the raw sewage quality flowing into municipal wastewater treatment plants were analysed. The analysis covered 7 WWTPs from the years 2003-2018.

During the analysis of the collected data, it was found that the TSS in subsequent years and in various wastewater treatment plants are characterized by high variability. This was confirmed by the results of statistical analysis, especially the parameters of standard deviation and coefficient of variation. However, after aggregating and processing the data set from absolute values into relative values, it was possible to compare the results of measurements from different wastewater treatment plants with each other. The obtained trend in the period 2003-2018 illustrates a small but distinct increase in the value of TSS in municipal sewage discharged from various communities. 
In the case of the $\mathrm{BOD}_{5}$, a similar distribution of statistical analysis was found as in the case of total suspended solids. Only a small trend related to the increase of $\mathrm{BOD}_{5}$ was observed in the years 2003-2018.

It can be stated that in the case of TSS, a visible increase in concentration has been observed in the last 15 years, which may be related to the trend of decreasing the water consumption in households. However, this process is very complex and the composition of municipal sewage discharged from households is influenced by many different factors. Nevertheless, the results of the research confirm the change in the composition of wastewater in recent years.

\section{REFERENCES}

1. Bortnowski S. 1975. Instalacje wodociągowe. Wydawnictwo Politechniki Warszawskiej, Warsaw.

2. Chudzicki J., Sosnowski S. 2011. Instalacje wodociągowe - projektowanie, wykonanie, eksploatacja. Seidel-Przywecki, 3rd edition, Warsaw.

3. Gabryszewski T. 1978. Instalacje wodociągowe i kanalizacyjne. Arkady, Warsaw.

4. Imhoff K. 1933. Zasady kanalizacji miast i oczyszczania ścieków. Centrala Wydawnictw Higienicznych przy Państwowym Zakładzie Higieny, Warsaw.

5. Imhoff K. 1957. Kanalizacja miast i oczyszczania ścieków. Guide, Budownictwo i Architektura, Warsaw.
6. Imhoff K. 1970. Kanalizacja miast i oczyszczania ścieków. Guide, Arkady, Warsaw.

7. Imhoff K. 1982. Kanalizacja miast i oczyszczania ścieków. Guide, Arkady, Warsaw.

8. Imhoff K., Imhoff K. 1996. Kanalizacja miast i oczyszczania ścieków. Guide, Projprzem, Bydgoszcz.

9. Janczewski H. 1973. Zapotrzebowanie wody w miastach w latach 1969-1990. PZiTS-Arkady, Warsaw.

10. Regulation of the Minister of Infrastructure of 14 January 2002 on determining average consumption of water per person in households (Journal of Laws. no 8 pos. 70, 2002).

11. Sytek-Szmeichel K., Heidrich Z., Stańko G. 2016. Dane wejściowe do projektowania miejskich oczyszczalni ścieków (według stanu na koniec 2015 r.). GWITS nr 7/2016, Warsaw, p. 272-276.

12. VDI 6024:2003. Verein Deutscher Ingenieure-Richtlinien. Wasser sparen in der Sanitärtechnik.

13. Wojnarowicz S. 1955. Wodociągi. Budownictwo i Architektura, Warsaw.

14. Wóycicki K. 1948. Wodociągi i kanalizacje. Ministerstwa Odbudowy No 23, Warsaw.

15. Wóycicki K. Wodociągi. 1954. Budownictwo i Architektura, Warsaw.

16. Dimensioning of Single-Stage Activated Sludge Plants ATV-DVWK A131 P, 2001.

17. Technical guidelines designing the size of a municipal water supply system in terms of water demand. Regulation nr 8 of the Ministry of Communal Management (Trade Journal no 16, pos. 68, from 9.12.1966). 